\title{
Dominican and Jesuit Theologians at an Ecumenical Council: Yves Congar and Karl Rahner
}

\author{
Thomas F. O'Meara, O.P. \\ University of Notre Dame, emeritus, Notre Dame, IN, USA \\ thomas.fo'meara.1@nd.edu
}

\begin{abstract}
The Second Vatican Council was not only a meeting of bishops from around the world, it was also an assembly of theologians. Prominent among those gathered were the Dominican theologian Yves Congar and the Jesuit theologian Karl Rahner. Both offered a positive theology of grace outside of Christianity, an embrace of true inculturation within the church, and both saw the council as a beginning in opening up the church to theological variety appropriate to become a global presence in a new era. During the council, Congar and Rahner worked together, developed a friendship, and found that they had harmonious theological perspectives that allowed them to become valuable allies in shaping the final outcome of the council.
\end{abstract}

\section{Keywords}

Second Vatican Council - Yves Congar - Karl Rahner - Jesuits - Dominicans theology of grace

The process, education, and results of the Ecumenical Council Vatican II were formally in the hands of the bishops present. That council, however, was also very much a gathering - an assembly of theologians. Learned and creative figures like Henri de Lubac (1896-1991), Hans Küng (b.1928), John Courtney Murray (1904-67), and Gregory Baum (1923-2017) were members of the commissions drafting the conciliar documents. They gave lectures almost daily to the bishops in their national groups. ${ }^{1}$

1 See Yves Congar, “Les théologiens, Vatican II, et la théologie," in René Rémond, ed., Le Concile de Vatican II (Paris: Beauchesne, 1984), 79-90. 


\section{Theologians Meeting}

This coming together of dozens of theologians in Rome to inform the deliberations of bishops had been prepared for by fifty years of Catholic theological renewal in northern Europe. The theologians had their own schools, academic specializations, languages, and ecclesial traditions. Not a few belonged to religious orders like the Society of Jesus and the Order of Preachers. There seems to have been, after each of the world wars, a fruitful time for congregations and orders, as they attracted an unusual number of talented people. And too theology, as speculative as it was, listened to the call for pastoral renewal in the church. New (and old) movements ranging from individual preparation for the sacraments to groups of priest workers resulted from Catholics calling for change. Fifteen years of ecumenism, biblical study, liturgical restoration, and attention to wider ministries followed World War II. Curiously, part of the history of this vitality and expansion inspiring the church in northern Europe was persecution. ${ }^{2}$ Disciplinary actions issued in the 1950 s by the Vatican sought to limit the teaching and publishing of significant theologians. This, however, strengthened their resolve to work harder for renewal in the church.

Among the many creative theologians at Vatican II, two theologians, one a Jesuit and one a Dominican, had a significant impact. Born the same year, 1904, the contours of their lives were, nonetheless, different. Karl Rahner (1904-84) was from Freiburg im Breisgau on the Rhine beneath the Black Forest. He was a Jesuit; his doctoral studies were basically in philosophy. Yves Congar (1904-95) studied the history of the structures and teachings of the church; over decades, he catalogued topics and ideas from publications in ecclesiology appearing in Europe and around the world. Congar's family lived in Sedan in northeast France, although the family's origin lay to the west in Celtic Brittany. Congar was also a pioneer of Roman Catholic ecumenism with Protestant and Orthodox churches. Rahner was a fundamental theologian attentive to the thoughtforms of Thomas Aquinas (c.1225-74), Immanuel Kant (1724-1804), and Martin Heidegger (1889-1976). He looked at the renewal of the local church serving the individuality of Christian existence. Congar published creative writings in

2 Thomas F. O'Meara, "Raid on the Dominicans: The Repression of 1954," America 170 (1994): $8-16$. 
his early thirties; but less so after he was sixty-five. Rahner began to be known when he was approaching fifty, and his originality lasted until his death when he was eighty.

Among the theologian-experts at the council, the periti, these two stood out. Illustrative is an entry in Congar's diary for the end of the council on December 7, 1965: "I left the Basilica slowly and with difficulty; a number of bishops congratulated me, saying that this was very much my work. Looking at things objectively, I did do a lot to prepare for the Council, to elaborate and diffuse the ideas the Council made its own. At the Council itself I worked a lot." He lists sections of the documents on the church and on revelation that are from him as well as the introduction and conclusion of the texts on ecumenism and on non-Christians. Parts of the documents on foreign missions, on priests, and on religious liberty are by him. "In short, this morning, that which was read came very extensively from me."3

Rahner showed the conciliar theologians how to be Catholic and modern, how to help Christians see their faith and church from a personal and developmental perspective. Theology was not an academic discipline but a communication of, an access to, the realities of faith for people who live amid their understanding of self and world in a particular time. ${ }^{4}$ Rahner spoke of his work at the council in this way: "I would not say that I preformed anything special that one could pin down. I did work very hard, and it was frightfully tiring work. I can hardly imagine how each decree, in some cases after hundreds of suggestions for corrections from bishops and others, finally found a formulation

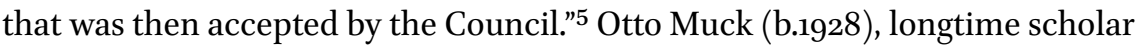
of the course of modern philosophy and theology within Catholicism, wrote: "Karl Rahner influenced in a decisive way theological thinking in this century. A source of this efficacy was his profound knowledge of theological tradition and its sources [...]. He had a sense of the concrete person with its experience and concerns as well as perspectives from transcendental-anthropological

3 Yves Congar, Mon journal du Concile II (Paris: Cerf, 2002), 510f. Richard McBrien wrote of him: "By any reasonable account, Yves Congar is the most distinguished ecclesiologist of this century and perhaps of the entire post-Tridentine era. No modern theologian's spirit was accorded fuller play in the documents of Vatican II than Congar's" (Richard McBrien, "Church and Ministry: The Achievement of Yves Congar," Theology Digest 32 [1985]: 203-11, here 203). For closer list of his contributions, see Hervé Legrand, "Yves Congar (1904-1995): Une passion pour l'unité," Nouvelle revue théologique 126 (2004): 529-54, here 536f.

4 Karl Rahner, "Grundsätzliche Überlegungen zur Anthropologie und Protologie im Rahmen der Theologie," in Mysterium salutis 2 (Einsiedeln: Benziger, 1965), 406-20, here 406.

5 Paul Imhof and Harvey Egan, eds., Karl Rahner in Dialogue: Conversations and Interviews, 1965-1982 (New York: Crossroad, 1986), 262. 
philosophy." 6 These contributors to Vatican II influenced the life of Christians from the liturgy to the papacy.

\section{Theological Co-Workers}

The interaction and friendship between the two theologians indicate the harmony between theological perspectives active at Vatican II. Congar was often with Rahner in conciliar meetings, and the Dominican found him valuable. In May of 1963, he wrote: "Rahner monopolized the conversation a little too much. He is magnificent, he is courageous, he is perspicacious and profound." ${ }^{7}$ Once the reactionary Vatican official Alfredo Cardinal Ottaviani (1890-1979) angrily confronted Congar about sharing Rahner's dubious ideas. Congar said that he had not worked on that particular text, but, regardless, "Karl Rahner is my friend." 8

Congar chose as one of the themes to be developed in a book of essays, The Wide World My Parish: Salvation and Its Problems, the reality that Rahner sought to interpret throughout his life: human existence as the place of God's self-sharing throughout the world. ${ }^{9}$ The originality of Rahner's position

consists in placing this universal will of salvation in strict relationship with human Dasein, with the human condition; it assures to the human person an existential that is a supernatural horizon of grace like a horizon of the realization of nature; the one is given with the other and they have similar dimensions. The supernatural suits the transcendental framework in which spiritual consciousness experiences being: a history

6 Otto Muck, "Heidegger und Karl Rahner," Zeitschirft für katholische Theologie 116 (1994): 25769, here 267. "His theology," Karl-Heinz Neufeld concluded, "entered in a particular way into people's lives [...]. In his own way he let the ordinariness of human life meet the Christian mystery so that every aspect of life could be penetrated by that mystery. Above all he recalled forcefully the clarity of what is Christian, of what contribution Christian faith could make to an age that often did not get beyond problematics and frameworks of questions" (Karl Neufeld, "Karl Rahner-Zeitgenosse," in Hans-Dieter Mutschler, ed., Gott neu buchstabieren: Zur Person und Theologie Karl Rahner [Würzburg: Echter, 1994], 13-35, here 35).

7 Yves Congar, Mon journal du Concile, 1:382. "His kind of personality with its marked intellectual honesty" (Congar, Mon journal du Concile, 2:440).

8 Congar, "Erinnerungen an eine Episode auf dem II: Vatikanischen Konzil," Elman Klinger and Klaus Wittstadt, eds., Glaube im Prozess: Christsein nach dem II. Vatikanum: Für Karl Rahner [Freiburg: Herder, 1984], 31-32.

9 Yves Congar, The Wide World My Parish: Salvation and Its Problems (Baltimore: Helicon, 1961), 17 . 
of salvation, of revelation, and of faith coexist with the history of humanity. In accepting oneself a person realizes between the individual and God a rapport in which God communicates something of the divine life to the person and in which the person posits supernaturally an act of faith. But such an act, like every personal act, must take concrete form, not only out of the individual life, but as it suits human nature socially. ${ }^{10}$

Congar then noticed the influential shift furthered by Rahner in Catholic life from fixation on a mechanics of transitory graces to the Spirit enabling grace as an intrinsic quasi-principle of life, e.g., from rites to sacramentality.

\section{$4 \quad$ Theology and the World}

In June 1965, when I was in the midst of my doctoral studies at the University of Munich, I went over to attend a session of a seminar at Karl Rahner's Institut für Religionsphilosophie und Christliche Weltanschauung. As I entered the office and seminar room, I noticed a stack of copies of a document— the long European pages mimeographed and stapled. It was a text he had written for the council that would find in the coming autumn its concluding session. I asked if I could have a copy and was given one. ${ }^{11}$ This was Rahner's critique of the most recent draft of Schema XIII (as Gaudium et spes was initially designated). He served on the committee laboriously preparing this innovative and important document. Among several meetings for the third session was an important one near Rome. "Rahner was invited to the well-known meeting at Ariccia in the Alban hills outside Rome [...], an invitation he could not accept since as an employee of the state he could not be absent for half a month from his professor's lectures in Munich."12

Rahner's critique is extensive, ranging from the weak Latin style and grammar of the text to the needed existential analyses of world and salvation history. The draft he is examining lacks adequate social and eschatological dimensions and is too abstract and too positive. There needs to be a fundamental

$10 \quad$ Yves Congar, "Les religions non bibliques sont-elles des médiations de salut?," in Ecumenical Institute for Advanced Theological Studies: Year-Book 1972-1973 (Jerusalem: Tantur, 1973), 77-102, here 82.

11 The title was "Anmerkungen zum Schema De ecclesia in mundo hujus temporis" (in der Fassung vom 28. 5. 65); "Remarks on the Schema, De Ecclesia in mundo hujus temporis, in the draft of May 28, 1965." The text was in Latin.

12 Günther Wassilowsky, Universales Heilssakrament Kirche: Karl Rahner's Beitrag zur Ekklesiologie des II Vatikanums (Innsbruck: Tyrolia, 2001), 96-97. 
theology of how the average Christian believer reflects on the world. Is knowledge of the world today solely profane? Can faith illumine the world's structures and enterprises? The foundation of the texts should be an adequate Christian anthropology treating the human supernatural vocation and the human person as the image of God. Rahner emphasized that there is too a lack of a serious theology of sin, of original sin, personal sin, and social sin. There should be further attention to the relationship, the distinction, and the mutual inclusion between the order of creation and the order of redemption. There is a tonality in the text that is abstract, even serenely distinct, apart from the world. The church should state the limits of its faith when it is seeking to solve concrete problems and should remember that he statements of Christian moral principles do not always give concrete answers. Finally, the eschatological goal and situation should be stronger, "a theology of the supernatural and completing elevation of all of the created order aimed toward the immediate possession of God." Some have seen Rahner's critical pages as exemplifying German theology at Vatican II in contrast to a more optimistic, more progressive, more developmental French theology. The document, of which I received a copy, according to Günther Wassilowsky (b. 1968) "has observations that are extraordinarily rich for the research of the 'German' theological approach in terms of Gaudium et spes." 13

Congar's contributions to this document showed his theology. He was part of the French church when movements in social action, liturgy, and politics sought improvement. He and his confrères had had direct contact with the ecclesiologically alienated and the socially impoverished. His view of the church in today's world begins with a historical prelude from 1500 to Vatican II. It looks at the image of the church and its activities in witness, community, liturgy, and service. Society exists within circles of ecumenism including Eastern Christianity and on to world religions. An anthropology of the image of God leads to a Christian ethics. Precise issues for the individual, e.g. sexuality, are listed and then spheres of politics, Marxism, and the needs of society. Two extremes are not acceptable: "A sacred cadre without human truth and a secularization without a divine dimension. The Council has wanted to be a force for integration." ${ }^{14}$ There is usually a tension in the church between a clerical, ceremonial church, and another church born of the Gospel and aiming at the generous program given by Jesus enabling greater life for people. Here a

13 Wassilowsky, private correspondence with the author from May 13, 2008.

14 Yves Congar, Église catholique et France moderne (Paris: Hachette, 1978), 278. For the development of these directions after the council, see his Un peuple messianique: Salut et liberation (Paris: Cerf, 1975). 
theology of precise groups was joined to an optimism stimulated by a history of salvation more than by social problems and evils. ${ }^{15}$

\section{Personal Contacts}

I was fortunate to have some minor contacts with both theologians. One day in 1964, I had just said goodbye to relatives among the splendors of Rome. I was visiting on the street with a Dominican from my province, a friar who was doing a doctorate in canon law in Rome. During the council, Bertrand Ebban (b.1932) was a theological adviser to the bishops of Nigeria; for some years, he had lived and worked in Nigeria at Dominican parishes and schools there. A long black automobile pulled up next to us in the street. With difficulty Congar got out. He gave my Dominican friend a stack of mimeographed dossiers. "For the bishops of Nigeria - and right away!" Congar said. He then got back into the car with difficulty, and they drove away. The bishops of Belgium had found rooms for Congar at a Belgian institute, and because the Dominican was increasingly hindered by a neurological disease, they found a car and a driver for him. Congar was always in a hurry, writing down his many ideas and their sources, and then distributing the pages of his commentaries on the drafts of the council's texts. Those pages of the texts for each session, he said, "were as numerous as the leaves falling from the autumn trees in Rome." The work of the council pressed upon him.

I was sent to Munich, Germany for doctoral studies. I was in my second semester there as Rahner arrived to join the faculty as Romano Guardini's (18851968) successor in an interdisciplinary professorship of "Philosophy of Religion and Christian World-View."16 To hear his opening lecture, I entered the University's main building, and found a seat in the crowded Auditorium Maximum. A short figure in black suit and tie began to describe his intention to unfold the most basic ideas of Catholic Christianity. Rahner appeared during his lecture as both meditative and energetic; he was, I would learn, unassuming but also passionate. "The student"-I wrote down some words from his opening lecture- - "has a responsibility to understand courageously the intellectual and

15 See Giovanni Turbanti, Un concilio per il mondo moderno: La redazione della constituzione pastorale Gaudium et spes del Vaticano 2, vol. 22 (Bologna: Il Mulino, 200o); on both theologians in this area see Barbara Ann Finan, "The Mission of the Holy Spirit in the Theology of Karl Rahner" (PhD diss., Marquette University, 1986).

16 Thomas O'Meara, "Romano Guardini's Akademische Feier in 1964," in Robert A. Krieg, ed., Romano Guardini: Proclaiming the Sacred in a Modern World (Chicago: Liturgy Training Publications, 1995): 98-103. 
cultural powers of the time." Those lectures appeared in 1976 as Foundations of Christian Faith (London: Darton Longman \& Todd). Rahner, modest and approachable, did not fit the type of the "Herr Professor." He had no interest in prestige or in power; in interviews he described his life as without anything distinctive, not the life of an academic or an ecclesiastic but of an ordinary person wanting to make the Gospel credible to the people he met.

Both theologians were much more than scholars researching footnotes in a library (although they had extensive knowledge of the history of theology) and spent their lives among people and students to whom they gave ready and friendly access.

\section{Renewing the Roman Catholic Church}

These significant teachers, along with most of their co-workers at the council, grew up in a Europe that was reconsidering Christian teaching, theological expression, and pastoral ministries. After 1925 and after 1945 the Roman Catholic Church needed to enter into a renewal, a revitalization in order that it might present the Gospel in a positive and attractive way. That renewal touched a broad spectrum of church ideas and institutions. Churches and schools north of the Alps were breaking out of a sterile intellectual framework. After the middle of the nineteenth century the Vatican had labored strenuously to impose a monopoly on the church throughout the world: one philosophy and similar philosophical theology drawn from medieval Scholasticism to defend doctrinal definitions and ecclesiastical laws. The years passed, and that new version of "school-thinking" dominant from Vatican I (1869-70) to Vatican II turned out to be not the best of medieval thought and not really the theology of Aquinas. It was mainly philosophical, a textbook collection of definitions and divisions, largely Aristotelian. One of its forms claimed to be the thought of Aquinas, a neo-Thomism. However, according to Otto Pesch (1931-2014), that neo-Thomism held the real theology of Aquinas "under house arrest."17

Franciscans and Benedictines, Dominicans and Jesuits, the universities of Leuven and Munich — each developed a more accurate, richer, and Christian expression of medieval thinkers. At times and places in the twentieth century philosophers and theologians discerned seminal basic ideas and found principles capable of pastoral renewal. Congar's mentor was the medieval scholar of the structure and synthesis of Aquinas, Marie-Dominique Chenu (1895-1990).

17 Otto Pesch, Thomas von Aquin: Grenze und Grösse mittelalterlicher Theologie (Mainz: Matthias-Grünewald, 1989), 27. 
He founded a school emphasizing historical research and contemporary engagement. In that French Dominican studium with its theological approach Congar studied and then taught. History was the way to bring forth past ages and thinkers of life, and history inspired contemporary renewal. Thomas was-not only in the thirteenth century but in the sixteenth and twentietha dynamic force for vitalizing the church. It was a question of seeing Christian ideas and church forms in their historical vitality and then employing them to re-structure the church, local and universal. ${ }^{18}$

The two theologians took theology into a new era. Both emphasized the freedom of the person with its modes of participation in the sacramental, as matter and spirit. Rahner too was a gifted student of the medieval Dominican..$^{19}$ He was part of the movement among Francophone and German Jesuits after 1910 to dialogue with modern philosophers. The attention of philosophy after Kant, Friedrich Wilhelm Joseph von Schelling (1775-1854), and Georg Wilhelm Friedrich Hegel (1770-1831) to a creative self and a pneumatic history found potential for dialogue in Aquinas' exposition of psychology and an anthropology of grace. A small group in the church argued that philosophy, transcendental and existential, could contribute theologies, not at all heterodox,

18 "Everything is absolutely historical including the person of Jesus Christ. The Gospel is historical. Thomas Aquinas is historical, Paul vi is historical. Note that historical does not mean just that Jesus came at a certain point in time but that one must draw today the consequences of this fact, He is conditioned by the time in and through which he lives" (Jean Puyo, Jean Puyo interroge Yves Congar: "Une vie pour la verité" [Paris: Le Centurion, 1975], 43).

19 Of course, Rahner too wrote on topics in the history of theology: studies on the fathers of the church and on the history of the sacrament of penance (see Brandon Peterson, "Karl Rahner on Patristic Theology and Spirituality," Philosophy \& Theology 27 [2015]: 499-512). He also was concerned with the local church, editing a multi-volume pastoral theology (Karl Rahner and Daniel Morrissey, Theology of Pastoral Action [New York: Herder and Herder, 1968]; Thomas F. O'Meara, "Karl Rahner on "Karl Rahner on Priest, Parish, and Deacon," Worship 40 [1966]: 103-10). Congar, while little concerned with metaphysics, had a central relationship to modern philosophy. He found that Johann Adam Möhler (17961838), with his synthesis of the Romantic historical idealism of Friedrich Schelling and Eastern patristic thought, offered ways of thinking and being that led from a church resembling a pyramid to an organic, active, varied community of ministries-namely, St. Paul's Body of Christ ("Revelation and History: Schelling, Möhler and Congar," Irish Theological Quarterly 53 [1987]: 17-35); "Beyond 'Hierarchology': Johann Adam Möhler and Yves Congar," in Donald J. Dietrich and Michael J. Himes, eds., The Legacy of the Tübingen School: The Relevance of Nineteenth-Century Theology for the Twenty-First Century (New York: Crossroad, 1997), 173-91. Congar wrote, recalling Schelling's philosophy of organic history: "The church is a living being that knows itself only in its life and becomes explicitly conscious of its own reality and of its possibilities precisely as it realizes them" (Chrétiens désunis [Paris: Cerf, 1937], 317). 
that spoke to and influenced the cultures of the twentieth century. Rahner like Aquinas centered his work on grace as life-principle, shifting attention from the mechanics of actual grace to the presence of God's self-communication.

\section{German and French Theological Cousins}

Within the pastoral and existential, historical and systematic contours of these two theologies were the influences of Dominican and Jesuit spiritualities. Congar wrote a little on Catherine of Siena (1347-80) and the Rhineland mystics, although he clearly considered Aquinas's theology to be the foundation and breadth of his order's spirituality. A considerable number of scholarly and popular writings have explored Rahner's creative fidelity to Ignatius of Loyola (c.1491-1556). He too, however, has aspects of a Thomist spirituality because of his knowledge of Aquinas and because of Aquinas's influence on the spirituality of the Society of Jesus. Rahner and Congar were nourished by a few great Christian thinkers among whom were key figures in spirituality. The world around them drew out themes and ecclesial movements for today and the future - that was their further spirituality.

The two theologies are frequently marked by the same thought-forms and goals of the post-conciliar years. They are seminal, historical, and global. The church was moving from a past set of precise teachings or religious rituals back to sources in the New Testament and the first decades of the church, to the pneumatic reality that grounded a ritual or a canon manifesting the papacy. Sacramentality or ministry had a source and history greater than Baroque episcopal vestments or Latin canons. After the council Rahner wrote:

A church that functions in an authoritarian approach as the old-fashioned companion of a secular and emancipated society is uninteresting and historically dead. People who-ultimately for personal, psychological reasons-remain in that kind of church want it to be a humanitarian organization or a swindle resembling secular social power. ${ }^{20}$

In the incarnational process of the Christian church underlying ("transcendental") sources led historical forms and ideas to become concrete ("categorical") in new ideas and expanded ecclesial ministries. The challenge for the final decades of the twentieth century, the challenge of an ecumenical council, was

$20 \quad$ Karl Rahner, "Opposition in the Church," Theological Investigations, vol. 17 (New York: Crossroad, 1981), 127. 
to liberate Christian realities and forms so that they could give a newness of grace to believers in their church. Both men saw that changes would take place not just in Europe but in "a wide world," in "a global church." Congar wrote: "The requests from Africa or Asia for a true inculturation are authentic requests from the church as its moves in the journey of the human race."21 Both offered a positive theology of grace outside of Christianity. ${ }^{22}$

Observations on the relationship of Congar to Rahner find an appropriate conclusion in some pages written in 1979 by the French Dominican for a German volume honoring Rahner. Congar contributed to this Festschrift not the usual historical study but an entertaining literary improvisation. This was a letter from Aquinas to the Jesuit theologian. It was composed by Congar as if written by Aquinas. Congar/Aquinas first offers some similarities and differences between himself and the modern Jesuit, humorously observing that from his writings from the thirteenth century "not a word can be removed or added." On the contrary, he found in Rahner "sentences with thirty lines and in the midst of that, set off by dashes, an insert of fifteen lines." ${ }^{23} \mathrm{He}$ observes that both he and Rahner had been condemned by ecclesiastical authorities. Moving to theological considerations he writes: "Both of us have a deep trust in the idea [...], in the content of an essential idea and of trust in pursuing it."24 What is distinctively of Rahner is singled out:

I must say that I agree with your idea of grace as an 'existential' of the concrete existing human person, because we do actually live in a

21 Congar, "Situation au moment de 'Ecclesiam suam," in Congar, Concile de Vatican, 2:32.

22 Congar wrote: "That to which Rahner gave the name 'anonymous Christians' is an authentic reality in terms of the condition of people not evangelized but nevertheless justified by the grace of Christ [...]. It is the term that is questionable" ("Les religions non bibliques sont-elles des médiations de salut?," 84). He struggled with the categorical reality of religion. In terms of the ordinary mediation of salvation through (not in spite of) religions, an effect of God's permissive will, Congar agreed with Rahner's discussion of legitimate religious institutions helpful towards obtaining salvation and positive in the plan of God (“Les religions non bibliques sont-elles des médiations de salut?," 85. On wider grace in the two theologians see Thomas F. O'Meara, "Yves Congar, Theologian of Grace in a Wide World," in Gabriel Flynn, ed., Yves Congar: Theologian of the Church (Louvain: Peeters Press, 2005; 2018), 371-400.

23 Yves Congar, "Loving Openness Toward Every Truth: A Letter from Thomas Aquinas to Karl Rahner," Philosophy and Theology 12, no. 1 (2000): 213-16, here 213.

24 Congar, "Loving Openness," 215. 
supernatural order which encompasses the natural [...]. An "objective redemption" which means that human persons are really redeemed; they exist in a real order of salvation. Only if a person rejects this (corresponding to the conditions of their knowledge and their possibilities) do they fall away from the salvation of Jesus Christ. Certainly that seems to me to occur at a concrete existential level. The questions emerge on the level of the analysis of the essential structures of this, on the level of that which you call transcendental anthropology. ${ }^{25}$

The grace of God is offered in each personal activity and is accepted or rejected by every man or woman. Aquinas in his letter then takes a different direction and disagrees with Rahner in a few concrete issues: namely the office and designation of the bishop, and then of the pope, and in the role of the concrete life and teaching of Jesus in Christianity and history. In the final lines Congar salutes Rahner:

But I don't want to conclude my letter without expressing how very much I value the way, the style, in which you have formulated anew so many issues. I am your predecessor. I wear a different habit than you (and some have placed a sun on my chest and a circle of light on my head), but you are my brother, and I embrace you. Vale! Thomas Aquinas of the Friars Preachers. ${ }^{26}$

\section{$9 \quad$ Conclusion}

Yves Congar was the most important Catholic theologian in the decades before Vatican II; after the council, that was Karl Rahner. ${ }^{27}$ Both theologians were realists. They saw faith and its expression to be about realities, evangelical and existential, pneumatic and human. Christian realities are expressed within cultural epochs and serve the future. Vatican II was not a bookstore of documents but an "event." Congar wrote of salvation history as a sequence of movements and persons in their own worlds. Grace is "a source of living experience for men and women."28

25 Congar, "Loving Openness," 218.

26 Congar, "Loving Openness," 219.

27 Leo O'Donovan, “A Final Harvest: Karl Rahner's Last Theological Writings," Religious Studies Review 11 (1985): 357-61.

28 Yves Congar, "Marie-Dominique Chenu," in H. Vorgrimler and R. Vander Guchts, eds., Bilanz der Theologie im 20. Jahrhundert: Bahnbrechende Theologen (Freiburg im Breisgau: Herder, 1970), 105 . 
Both saw the council as a beginning in multiple areas - in theological variety, in movements, and in a global presence. The dynamics of history empower the future:

The dynamism of the Council is not purely commemorative, retrospective, or repetitive. Tradition is always creation at the same time; as it is transmission it is reference. This ecclesial process is a burdensome task. But it is valuable to present information, creativity, study, listening, and dialogue, activities that obliges all in the church. The future of the council will be re-actualization of the depth of the conciliar work, that collaboration between pastors and theologian in which all receive each other. $^{29}$

Rahner, once the Council was ended, looked at its immediate future:

The one church of the future will not be the Roman Catholic Church in the form that exists today. It will be marked by a legitimate pluralism, a greater pluralism [...]. The church will be made up of a network of basic communities with some kind of organized inter-relationship. This commonality will be assured by the bishops [...]. The Church will have a greater significance throughout the world than it has today. ${ }^{30}$

Students of history, they interpreted the forms and teachings of Christianity out of different historical contexts for today. The global church at the end of the twentieth century needed new theologies and ministries to express and live the Gospel in ways suited to and attractive to global cultures already beginning a next age.

29 Congar, "Les lendemains de conciles," 2:107.

30 Rahner, Faith in a Wintry Season (New York: Crossroad, 1989), 161f. 